\title{
Development of Academic Writing Block Scale (AWBS): A Validity and Reliability Study
}

\author{
Ersin Gülay* \\ Department of Turkish Education, Recep Tayyip Erdoğan University, Rize, Turkey. \\ ORCID: 0000-0001-6476-1624
}

\author{
Suat Ungan \\ Department of Turkish Education, Trabzon University, Trabzon, Turkey.
} ORCID: 0000-0003-4020-6655

Article history

Received:

29.03.2021

Received in revised form: 07.08.2021

Accepted:

19.08.2021

Key words:

Academic writing;

Academic writing block;

Academic writing block scale, Scale development.
Academic writing block is a psychology-based writing problem that has a productivity-lowering effect on the publishing process. This study aimed to develop a valid and reliable assessment tool to measure academic writing block. To this end, during the pre-trial and trial applications, academicians were interviewed face to face. The main application was realized through the online form. A pre-reliability test, exploratory factor analysis (EFA) and total item correlation were conducted in the trial application. In the main application, reliability test, confirmatory factor analysis (CFA) and total item correlation were performed for construct validity. After the trial application, it was determined that the scale has a four-factor structure consisting of 23 items. Cronbach Alpha values were calculated to determine the preliminary reliability of the scale. CFA was conducted to test the construct validity of the Academic Writing Block Scale (AWBS). It was observed that the structure with four implicit variables determined in CFA was confirmed by the remaining 18 items in the scale. Besides, the total item correlation was used to test construct validity. Cronbach Alpha values were calculated to determine the reliability of AWBS. According to these values, it can be said that AWBS is a valid and reliable assessment instrument that can be used to measure academic writing block.

\section{Introduction}

Writing block refers to a particular condition in which author, despite his or her own will for writing, cannot produce enough (Rose, 1984). Boice (1983a), emphasizes the signs of writing block can be seen through "the anxiety of not being able to write". In other words, despite some attempts for writing it refers to a situation in which author suffers from not being able to write. Huston (1998), explains this issue as a "stress reaction against paralyzing agent of skills in which transforms thoughts into words".

\footnotetext{
* Correspondency: ersin.gulay@erdogan.edu.tr
} 
Turkish education specialists have devised and applied variety of different strategies to improve particularly primary, secondary, undergraduate students and prospective Turkish teacher candidates' abilities for academic writing skills. However, these strategies have failed to achieve aimed targets. The lack of progress for improving writing skills prevents the realization of the perspectives in the issue of writing block. Moreover, the fact that students and academics who have effective writing skills are either not writing enough or not able to write reveals the problem of academic writing block which has not hitherto received enough attention in the relevant literature.

Writing block refers particular condition in which author, despite his or her own will for writing, cannot produce enough (Rose, 1984). Boice (1983a), emphasizes the signs of writing block can be seen through 'the anxiety of not being able to write'". In other words, despite some attempts for writing it refers to a situation in which author suffers from not being able to write. Huston (1998), explains this issue as a "stress reaction against paralyzing agent of skills in which transforms thoughts into words".

When relevant literature is examined, one can identify writing block as one of the negative elements effecting entire writing process. Moreover, the issues of writing block as an independent factor reduces the success and quality of writing for students, academics, and other writers.

While the concept of "Writing block" appears in the writings of Royce (1898, as cited in Boice, 1985, p. 95-96) for the first time, in the literature it was defined and conceptualized by Bergler (1950, as cited in Castillo, 2014, p. 1043). Although the notion of writing block has been discussed and evaluated in international academic circles Turkish academics has just recently showed some interest towards the topic. The first available studies about writing block appears in the works of Akpınar (2007) using the writing block scale developed by Rose (1981); Zorbaz, (2010) used the same scale for primary school students. Despite these works, there is no original writing scale developed by Turkish academics.

Academic writing block can be defined as issues experienced by any authors in various stages of writing such as at beginning, during or in the conclusion as well as not being able to write articulately and accurately. Writing block can also cause some temporary or permanent hesitations. Academic writing skill is an important tool which plays a central role in publishing research findings. So that it requires not only an efficient postgraduate student or a scholar but also a very productive writer. On some occasions, following on the completion of successful research authors might experience some writing problems independently when they want to report their findings. Authorship that followed by research skills could come to come to a halt due to some internal and external reasons. Those students and academics who could not overcome these difficulties cannot make enough progress into their writing process.

There is no conceptual evidence for "academic writing block" in Turkish literature. This is evident in one of the very first works which belongs to Boice's (1990) block questionnaire for postgraduate students and academics that focuses on the structure of writing block and some related issues but fails to mention to the notion of "academic writing block". Yet, in the literature there are some scholarly works refer to the concept of (Birk, 2013; Cayley, 2018; Knox, 2017; Martineau, 2019) "academic writer's block" or "academic writing block". Having said that works on academic writing block covers mainly post graduate students and academics. (Birk, 2013; Boice, 1983a, 1983b, 1993, 1996; Boice \& Jones, 1984; Cayton, 1990; Elton, 2010; Hartley \& Knapper, 1984; Latta, 1995; Tucker, 1997). 
In addition to the existing gap in the literature, there is not also substantial body of work in the field investigating a possible link between the lack of high quality published academic works among Turkish scholars and academic writing block. It is evident that there is a strong correlation between academic productivity and academic writing block as according to TUBITAK (2016) the vast majority of published academic works come from universities and the lack of academic work is a great loss for Turkish academia.

According to TÜBİTAK (2020) data which shows that US is the most prolific country in producing academic work with 3.618.989 published articles between 2015-2019 and more importantly, academics have been investigating the causes and potential solutions of academic writing block for the last 40 years (Boice, 1990; Boice \& Jones, 1984; Cayton, 1990; Hartley \& Knapper, 1984; Lowenthal \& Wason, 1981; Tucker, 1997). Majority of these works focus on the psychological dimension of academic writing (Baker, 1988; Boice, 1993; Hall, 1998; Huston, 1998; Rose, 1984). In some of these works, authors put some emphasis on the link between academic writing block and social status, race, and gender (Birk, 2013; Cayton, 1990; Latta, 1995; Tucker, 1997). Chintamani (2014) and Rose (1984) emphasize the fact that academic writing block most commonly happen among skilled writers. Based on these works, it could be argued that academic writing bloc is one of the most serious obstacles in becoming a prolific writer.

According to the above-mentioned research (TÜBİTAK, 2016) Turkey ranked in $18^{\text {th }}$ place in the world with 204.216 published works between 2010-2015 and with 3,30 impact factor Turkey contributed $\% 1,50$ of total world published works. Although there are some important works about the problems of Turkish academics there is no concrete work focuses on the issue of academic writing block and productivity and the lack of scholarly work in the field causes a significant gap in the literature.

Recently, there has been an increase on the issue of writing block focusing on middle school and undergraduate students. However, there is still no reliable research about academicians writing block. The aim of this article is, therefore, to develop a quantitative academic writing block scale to fill existing gap in the literature.

In this article, academic writing block will be considered a common problem experienced by many academics rather than an individual issue. The issue of academic writing block studied heavily in 1980's has been neglected by the researchers; however in recent years there has been surge of researches in the field. (Baştuğ, 2015; Birk, 2013; Miller, 2010). From this perspective, this work will contribute to this ever-increasing body of scholarly work and paved the way for further research on the issue of academic writing block which is one of the less worked area in the process of academic writing.

Additionally, developing an academic writing block scale with some psychometric features will attract further research interest from Turkish scholars to improve the knowledge and understanding in the field. It is also anticipated that this scale will be one of the key tools to elaborate the relationship between psychology and skills for over academic writing process.

\section{Method}

This chapter will cover some subsections such as working group, preparing scale, validity, and reliability. 


\section{Working group}

To identify and explain the main points of the scale a pre-trial study was carried out with some 20 academics. This study was carried out with academicians working in the faculty of education, considering the criterion of easy accessibility and the possibility of face-to-face application. These academicians work in the Departments of Turkish and Social Sciences Education, Computer and Instructional Technologies, Educational Sciences, Primary Education and Mathematics and Science Education.

The actual trial process was conducted right after the findings of pre-trial stage. At this stage, Comrey and Lee (1992, as cited in Erkuş, 2016a, p. 60) consider 50 participants as very insufficient, 100 participants as insufficient, 200 participants as appropriate, 300 participants good, 500 participants very good and finally 1000 participants as perfect number for an ideal number of required participants. Additionally, Kline (1994, as cited in Büyüköztürk, 2002, p. 480) states that 200 participants would be sufficient enough for reliable factors. 'The scale reflects total behavioral universe" so that in the study of scale, samples are collected against the features of measured items. In other words, in developing a scale it is important that researchers should not taking representative samples from an institution, region or country but from the features of measured items. At this point researchers need to find appropriate individuals potentially fit with features of research to apply and evaluate the scale (Erkuş, 2016b, p. 1126). Trial stage was conducted with 287 academics from Karadeniz Technical University and Recep Tayyip Erdoğan University. In this research different variables such as academic title, gender and field of academic discipline were applied, and participants were recruited on their suitability, willingness, and availability. To increase its validity, the scale was conducted face to face in participants' office. In doing so, researcher would be able to explain the scale in detail and answer participants' questions (Erkuş, 2016a, p. 61). The identifying information of the participants in the trial study was shown in Table 1 and Table 2.

Table 1. Distribution of the participants in the working group according to their academic title and gender.

\begin{tabular}{llllll}
\hline & Dr. & Assist. Prof. & Assoc. Prof. & Prof. Dr. & Total \\
Female & 8 & 51 & 20 & 7 & 86 \\
Male & 12 & 86 & 53 & 50 & 201 \\
Total & 20 & 137 & 73 & 57 & 287 \\
\hline
\end{tabular}

Based on Table 1 data, there are more male academics at every level than female academics.

Table 2. The distribution of the participants in the trial working group according to the academic field and title

\begin{tabular}{|c|c|c|c|c|c|c|}
\hline & & & $\begin{array}{l}\text { Assist. } \\
\text { Prof. }\end{array}$ & Assoc. Prof. & Prof. Dr. & Total \\
\hline \multirow{4}{*}{$\begin{array}{l}\text { Field of } \\
\text { Exam in } \\
\text { Associate } \\
\text { Prof. }\end{array}$} & $\begin{array}{l}\text { Department of Education } \\
\text { and Teacher Training }\end{array}$ & 5 & 42 & 18 & 6 & 71 \\
\hline & $\begin{array}{l}\text { Sciences } \\
\text { Mathematics }\end{array}$ & 1 & 9 & 10 & 8 & 28 \\
\hline & Philology & 2 & 6 & 1 & 3 & 12 \\
\hline & Theology & 1 & 15 & 3 & 4 & 23 \\
\hline
\end{tabular}




\begin{tabular}{llllll}
\hline $\begin{array}{l}\text { Architecture, Planning } \\
\text { and Design }\end{array}$ & 3 & 5 & 4 & 0 & 12 \\
$\begin{array}{l}\text { Engineering } \\
\text { Medical Sciences }\end{array}$ & 1 & 12 & 10 & 7 & 30 \\
& 4 & 15 & 4 & 5 & 28 \\
$\begin{array}{l}\text { Social, Human and } \\
\text { Administrative Sciences }\end{array}$ & 3 & 25 & 14 & 18 & 60 \\
$\begin{array}{l}\text { Faculty of Agriculture, } \\
\text { Forestry and Fisheries }\end{array}$ & 0 & 8 & 9 & 6 & 23 \\
& 20 & 137 & 73 & 57 & 287 \\
\hline
\end{tabular}

According to the distribution of academic title including the lecturers and academic field of associated professorship exam, Table 2 reveals that while most of the participants were recruited from departments of education and teacher training faculty and the least of them were recruited from the departments of philology, architecture, planning and design.

After identifying the factor structure of the scale, like pilot study, the researcher recruited his participants based on purpose sampling methods with maximum variables such as associated professorship exam field, academic titles, gender, representativeness, and heterogeneity. Prepared scales were sent to the academics who have completed their PhD. Working at Mediterranean University, Ankara Social Sciences University, Çanakkale Onsekiz Mart University, Erciyes University, Erzincan Binali Yıldırım University, Atatürk University, İstanbul University, İstanbul Medeniyet University, Karadeniz Technical University and Tekirdă̆ Namık Kemal University.

The field of examination in associated professorship, title and gender of the academicians who voluntarily filled in the scales were determined throughout the process, and it was followed whether the criteria for being heterogeneous in terms of the participants were met or not. To increase the heterogeneity of the research, prepared scale was sent to the scholars fit with research criterion working at Afyon Kocatepe University, Ankara Yıldırım Beyazit University, Dicle University, Dokuz Eylül University, Eskişehir Osmangazi University, Gaziantep University, Harran University, İnönü University, Marmara University, Ondokuz Mayıs University, Van Yüzüncü Yıl University, Yıldız Technical University via the mail addresses obtained from official websites. Cohen, Manion and Morrison, (2007, p. 238) states that the response rate for online scales might be $10 \%$ less than the paperback scales. Beside, Dillman and others $(1998$, p. 4) claim that only $84 \%$ of the participants completed the online questionnaire compare to $68 \%$ of the participants respond the same questionnaire in paperback. Hartley and Knapper (1984) provide response rate as $41 \%$ of 75 academics and $34 \%$ of 100 participants, and more importantly they classify these rates as low rate. Based on these studies which emphasize the fact that online questionnaires response rate will be low compared to paperback ones, total 15.109 scaled questionnaires were sent to the target scholars via Google Form, Gmail, Hotmail, and Yahoo. Only 711 (4,7\%) scholars which is lower than the expected, completed the questionnaire.

The main characteristics of the participants of this research are shown in Table 3 and Table 4 . 
Table 3. The distribution of the participants in working group according to gender and academic title.

\begin{tabular}{|c|c|c|c|c|c|c|c|}
\hline & & $\begin{array}{l}\text { Research } \\
\text { Assist. Dr. }\end{array}$ & $\begin{array}{l}\text { Lecturer } \\
\text { Dr. }\end{array}$ & $\begin{array}{l}\text { Assist. } \\
\text { Prof. }\end{array}$ & $\begin{array}{l}\text { Assoc. } \\
\text { Prof. }\end{array}$ & Prof. Dr. & Total \\
\hline & Male & 8 & 11 & 164 & 86 & 114 & 383 \\
\hline & Female & 13 & 13 & 174 & 69 & 59 & 328 \\
\hline Total & & 21 & 24 & 338 & 155 & 173 & 711 \\
\hline
\end{tabular}

In terms of gender distribution, Table 3 shows that there are more female scholars at the $\mathrm{PhD}$. Level than male academics. This trend reverses for the categories of associated professors and professors.

Table 4. The distribution of the participants in quantitative research group according to their academic titles and fields

\begin{tabular}{|c|c|c|c|c|c|c|c|}
\hline & & $\begin{array}{l}\text { Research } \\
\text { Assist. Dr. }\end{array}$ & $\begin{array}{l}\text { Lecturer } \\
\text { Dr. }\end{array}$ & $\begin{array}{l}\text { Assist. } \\
\text { Prof. }\end{array}$ & $\begin{array}{l}\text { Assoc. } \\
\text { Prof. }\end{array}$ & $\begin{array}{l}\text { Prof. } \\
\text { Dr. }\end{array}$ & Total \\
\hline \multirow{12}{*}{$\begin{array}{l}\text { Field of } \\
\text { Exam in } \\
\text { Associate } \\
\text { Prof. }\end{array}$} & $\begin{array}{l}\text { Faculty of Education and Teacher } \\
\text { Training }\end{array}$ & 2 & 7 & 45 & 24 & 20 & 98 \\
\hline & Natural Sciences and Mathematics & 1 & 2 & 30 & 17 & 9 & 59 \\
\hline & Philology & 0 & 0 & 11 & 4 & 6 & 21 \\
\hline & Fine Arts & 0 & 0 & 4 & 5 & 2 & 11 \\
\hline & Law & 1 & 0 & 7 & 3 & 3 & 14 \\
\hline & Theology & 2 & 0 & 12 & 6 & 5 & 25 \\
\hline & Architecture, Planning and Design & 1 & 0 & 9 & 10 & 2 & 22 \\
\hline & Engineering & 1 & 0 & 29 & 13 & 26 & 69 \\
\hline & Medical Sciences & 3 & 8 & 67 & 32 & 62 & 172 \\
\hline & $\begin{array}{l}\text { Social, Human and Administrative } \\
\text { Sciences }\end{array}$ & 6 & 6 & 94 & 25 & 31 & 162 \\
\hline & Sport Sciences & 0 & 1 & 7 & 4 & 0 & 12 \\
\hline & $\begin{array}{l}\text { Faculty of Agriculture, Forestry and } \\
\text { Fisheries }\end{array}$ & 4 & 0 & 23 & 12 & 7 & 46 \\
\hline Total & & 21 & 24 & 338 & 155 & 173 & 711 \\
\hline
\end{tabular}

In terms of academic title, Table 4 shows that more lecturers with Ph.D. participated to the questionnaire than research assistant; in terms of exams in the field associated professorship table shows that the most participants come from medical sciences and the least is from the department of fine arts.

\section{Preparation of Item Pools}

In the process of developing an assessment tool to measure the level of academic writing block, firstly existing relevant literature in the field was studied thoroughly (Baştuğ, Ertem, \& Keskin, 2017; Boice, 1990; Boice \& Jones, 1984; Castillo, 2014; Daly \& Miller, 1975; Daly \& Wilson, 1983; Erkuş, 2007; Erkuş, 2016a; Erkuş, 2016b; Hartley, 2008; Hartley \& Knapper, 1984; Hettich, 1994; Karakaya \& Ülper, 2011; Murray, 2015; Petzel \& Wenzel, 1993; Poff, 2004; Rose, 1984; Tezbaşaran, 2008; Yıldırım \& Şimşek, 2011; Zorbaz, 2010). Besides, two unstructured interviews about academic writing block were carried out with two scholars (Yıldırım \& Şimşek, 2011); 8 scholars were asked to produce a short article about experiences of academic writing block issues and effects. 
Erkuş (2016b, p. 52) and Tezbaşaran (2008, p. 14) state that it is necessary to prepare three or four times more items than the actual item pool which will reflect the structure of the conceptual framework of measured variables yet will remain within the framework. To justify this recommendation, they claim that researchers should have large item pool to substitute the items selected from the list which does not serve the purpose of the research. In doing so, researchers will be able to modify their item pool accordingly and effectively. All the resources are considered and made some inferences on the issue of academic writing block. These inferences then were converted into 41 different sentences which make up the total number of items in the pool.

\section{Content Validity}

To enhance revised scale and item pool for its content, clarity, punctuation, suitability, and measurability the researcher was consulted face to face with group of experts which consist of two scholars specialized in assessment and evaluation in education; an expert in developing scale, assessment, and evaluation in psychology; a professor in Turkish teaching, an associated professor, and two doctors. Additionally, items were also consulted via electronic mails with a professor of psychology who specialized in developing assessment and scale.

Furthermore, face to face pre-pilot study was conducted with 20 academics to test the understandability of items, total response time, grammatical errors, and typos (Erkuş, 2016b, p. 55); some feedbacks about clarity of scale and items were received. Following on these stages, the total 39 items were included in the pilot schema. The responses were organized in five-point Likert scale model as "always, frequently, sometimes, rarely, never".

\section{Structural Validity}

An exploratory factor analysis was applied to the items used in the pilot study to reveal the structure of the scale which was assessed with oblique rotation method. The scale with clear structure was applied to the different working group to obtain the analysis of construct validity. In the tables that shows findings of the research some abbreviations were used such as "AYT" for trial applications and "T" for the actual test.

\section{Findings}

\section{Experimental Application}

Prior to the explanatory factor analysis of data obtained from trial study, some statistical arrangements should be made such as missing values, reverse items, extreme values, normal distribution of data set, correlation between items, number of samplings and appropriate sampling (KMO and Bartlett sphericity test) (Field, 2013; Tabachnick \& Fidell, 2014). At this stage, firstly the values of the 19th item were corrected through reverse coding. After that it was confirmed that there is no missing value in the data set. While identifying multiple variables extreme values, all points for items were converted into standard points ( $\mathrm{Z}$ points) excluding point $|3|$ in the scale and the rest of the points were considered multiple variable extreme values not included in the analysis. In the analysis of the extreme values, the points which belong to the variables were converted into $\mathrm{Z}$ points and other than point $(|3|)$ all points were taken out of data set $(\mathrm{n}=8)$ (Tabachnick \& Fidell, 2014). Besides, histogram and box plot which are important for reflecting extreme values were also examined. In the third stage, Shapiro-Wilk test, histogram graphics, the closeness of the median and arithmetic mean values and the skewness-kurtosis coefficients $(|2|)$ were considered in the multivariate normality tests of the 
data set. In the examination of the skewness and kurtosis values of the variables, it was observed that there was no item other than the value (|2|) (Field, 2013; Kalayc1, 2016), which is accepted as the criterion in the relevant literature. Additionally, factorability of items was examined through anti-image correlation analysis and all items were found higher than .50 which is the acceptable correlation value according to Tabachnick and Fidell (2014).

The results of Kaiser-Meyer-Olkin (KMO) and Bartlett tests which are used to determine the suitability of factorial analysis of data set obtained from sampling in the scale are presented in Table 5.

Table 5. The results of AWBS Kaiser-Meyer-Olkin, Barlett Tests

\begin{tabular}{|c|c|c|}
\hline \multicolumn{2}{|c|}{ Kaiser-Meyer-Olkin measure of research adequacy } & .927 \\
\hline \multirow{3}{*}{ Bartlett Global value } & Chi-squared value & 4592,057 \\
\hline & Degrees of Freedom & 703 \\
\hline & $P$ value & $.000 *$ \\
\hline
\end{tabular}

*p<.001.

The value of KMO should be higher than .60 (Tabachnick \& Fidell, 2014). From the result of analysis, the value of KMO was found as .927 that proves the suitability of sampling for factorial analysis. Bartlett sphericity test presents statistically meaningful results as well as data coming from multiple variables normal distribution. These values show that the data set is appropriate to be used for explanatory factor analysis.

The purpose of factor analysis to determine the structure of the scale is to bring together a large number of variables in a measurement tool to reveal the relationships between them and to create a new factor or dimension with less conceptual integrity and to provide evidence that this measurement tool measures the same structure (Büyüköztürk, 2002; Tavşanc1l, 2010).

In the first stage of factor analysis, researchers should determine to work with either "total variance" or "common variance". If total variance is going to be applied then all types including error, specific, and common variances need to be considered in the analysis, or alternatively the principal component analysis for the common variance. Specific factor variances, which has an important place in social sciences with the human factor involved, is taken into account with item factor analysis (Suhr, 2005, as cited in Yaşlıoğlu, 2017, p. 76; Velicer \& Jackson, 1990, as cited in Yaşlıoğlu, 2017, p. 76). Common variance assumes of one-dimensionality of measuring tool. In this research, the total variance was used in the interpretation of items and factors by using principal component technique, one of the factorization analyses.

In the first stage, factor analysis carried out on 39 items. According to this analysis, the scale consists of 9 factors whose eigenvalue is greater than 1 and explains $61,541 \%$ of the total variance. To provide conceptual significance, rotation was performed to translate the obtained factors into new factors so that they can be interpreted better (Tavşanc1l, 2010, p. 49). Tabachnick and Fidell (2014) suggest that factors obtained using factor extraction methods should be interpreted by applying rotation.

According to Büyüköztürk (2002, p. 476), there are two types of rotation approach: vertical and oblique. Vertical rotation is based on the idea that there is no relationship between factors". De Vellis (2003, as cited in Polat, 2012, p. 13) states that the vertical rotation method is appropriate when the correlation between factors is less than .15. Table 6 shows the rates of the relationship 
between the factors of AWBS.

Table 6. Relationship between AWBS Factors

\begin{tabular}{|c|c|c|c|c|c|c|c|c|c|}
\hline Factor & 1 & 2 & 3 & 4 & 5 & 6 & 7 & 8 & 9 \\
\hline 1 & 1 & & & & & & & & \\
\hline 2 & .541 & 1 & & & & & & & \\
\hline 3 & .620 & .567 & 1 & & & & & & \\
\hline 4 & .307 & .097 & .181 & 1 & & & & & \\
\hline 5 & .546 & .437 & .389 & .176 & 1 & & & & \\
\hline 6 & .312 & .207 & .280 & .153 & .131 & 1 & & & \\
\hline 7 & .422 & .342 & .307 & .063 & .390 & .190 & 1 & & \\
\hline 8 & .137 & .093 & .035 & .196 & .235 & .007 & .222 & 1 & \\
\hline 9 & .298 & .297 & .185 & .022 & .330 & .079 & .225 & .230 & 1 \\
\hline
\end{tabular}

As seen in Table 6, the correlation values between the factors of AWBS were found to be .007 to .620 in this study. According to Osborne and Costello (2005, as cited in Polat, 2012, p. 12) and Tezbaşaran (2008, p. 477):

Particularly in social sciences, high correlations are observed between dimensions (factors). Because behaviours are rarely divided into neatly packaged units that function independently. Hence, using vertical rotation leads to the loss of valuable data if factors are related, and theoretically, oblique rotation offers more accurate and perhaps more reproducible solutions. If factors are not really correlated, vertical and oblique rotation will give the same results.

Tabachnick and Fidell (2001) suggest the promax rotation technique because it is more usable in the future than oblique rotation techniques to oblimin rotation (cited., Tezbaşaran, 2008, p. 477). In the light of these suggestions, promax, one of the oblique rotation techniques, was applied to reveal the best represented structure of the scale with the way the dimensions coincide with the conceptual structure. In this process, in the explanatory factor analysis process of AWBS, the opinions of a doctor, a doctor who is an expert in assessment and evaluation and a doctor who is a Turkish education specialist, a doctor lecturer, an associate professor and a professor doctor were consulted.

Stevens underpins (2002, as cited in Field, 2013, p. 1197), the significant correlation rate between dimensions and items is at least .512 for a 100 -person; .364 for a 200-person research group; .298 for a 300-person research group which indicates that it should be at least .21 for a research group of 600 people.

The common approach in the literature is that this value should be at least .30. Based on this, the cut-off value for the research group of 279 people in the study was established as .30. Also "the difference between two high load values is suggested to be at least .10 (Büyüköztürk, 2002; Tavşanc1l, 2010). Some of the items in AWBS have a factor load value less than .30, some load in more than one factor and the difference between these values is lower than .10; some items did not coincide with the conceptual structure of the dimension imposed on them. 
However, since two items were prepared for each of ten cases, it was decided to keep the highvalue items in the scale by comparing the factor load values of those items entering the same factor accordingly with the conceptual structure. Thus, a total of 23 items remained in the scale.

As a result of the explanatory factor analysis, the variance rates of the factors with eigenvalues greater than 1.00 are shown in Table 7.

Table 7. Eigenvalue and Variance Ratios for AWBS's Factors

\begin{tabular}{llll} 
Factors & Factor Values & Explained Variance $(\%)$ & Clustered Variance $(\%)$ \\
\hline 1 & 7,81 & 35,499 & 35,499 \\
2 & 2,251 & 10,234 & 45,733 \\
3 & 1,181 & 5,37 & 51,103 \\
4 & 1,06 & 4,819 & 55,922 \\
\hline
\end{tabular}

Looking at Table 7, the first factor (Motivation) with 8 items explains $35.499 \%$ of the total variance and it is seen that the eigenvalue of this factor is 7.810 .

The second factor (Assessment) with 8 items explains 10,234\% of the total variance and the eigenvalue of this factor is 2,251. The third factor (Procrastination), which consists of 4 items, explains $5,370 \%$ of the total variance and the eigenvalue of this factor is 1,181 .

The fourth factor (Perfectionism) consisting of 3 items explains $4.819 \%$ of the total variance, and the eigenvalue of this factor is 1.060 . AWBS explains $55.922 \%$ of the variance in total. Scherer et al. consider "The variance ratio between $40 \%$ and $60 \%$ as sufficient in social sciences." (1988, as cited in Tavşanc1l, 2010, p. 48) Based on its evaluation, it can be claimed that the scale measures the related structure well.

Table 8 shows the distribution of items by factors and their factor loadings.

Table 8. Factor Load Values of AWBS's Items

\begin{tabular}{llll}
\hline & \multicolumn{1}{l}{ Factors } & 2 & 3 \\
\cline { 2 - 4 } Items & 1 & & \\
\hline AYT22 & .821 & & \\
AYT27 & .815 & & \\
AYT35 & .746 & & \\
AYT21 & .738 & & \\
AYT24 & .681 & & \\
AYT9 & .672 & & \\
AYT14 & .666 & .821 & \\
AYT18 & .499 & .774 & \\
\hline AYT6 & & .762 & \\
AYT1 & & .746 & \\
AYT8 & & .733 & .857 \\
AYT10 & & .555 & .640 \\
AYT13 & & .537 & .453 \\
AYT2 & & .341 & \\
AYT7 & & & \\
AYT16 & & & \\
\hline AYT17 & & \\
AYT39 & & & \\
AYT26 & &
\end{tabular}




\begin{tabular}{ll} 
AYT33 & .390 \\
\hline AYT30 & .730 \\
AYT37 & .667 \\
AYT29 & .565 \\
\hline
\end{tabular}

When Table 8 is examined, it is seen that the factor loads of the items are between .341 and .857 .

To reveal the structure of AWBS, the item-total scale correlation test was used together with the explanatory factor analysis. Additionally, the reliability coefficient of the scale is calculated, and the results are presented in Table 9.

Table 9. Item-Total Test Correlation and Reliability Values

$\begin{array}{ll}\text { Item-Total } & \text { Item-Total } \\ \text { Correlation } & \text { Correlation (Within Cronbach Alfa } \\ & \text { Dimension) }\end{array}$

\begin{tabular}{llll}
\hline AYT22 & .495 & .740 & \\
AYT27 & .487 & .718 & \\
AYT35 & .554 & .783 & .85 \\
AYT21 & .504 & .686 & \\
AYT24 & .475 & .657 & \\
AYT9 & .496 & .673 & \\
AYT14 & .498 & .682 & \\
AYT18 & .591 & .678 & \\
\hline AYT6 & .697 & .812 & .87 \\
AYT1 & .545 & .659 & \\
AYT8 & .604 & .708 & \\
AYT10 & .722 & .790 & \\
AYT13 & .649 & .725 & \\
AYT2 & .599 & .653 & \\
AYT7 & .693 & .753 & .65 \\
AYT16 & .682 & .706 & \\
\hline AYT17 & .536 & .624 & .60 \\
AYT39 & .452 & .724 & \\
AYT26 & .389 & .686 & .723 \\
AYT33 & .672 & .740 & .731 \\
\hline AYT30 & .334 & .755 & \\
AYT37 & .541 & .527 &
\end{tabular}

If an item's item-total test correlation coefficient is .200 or less, the item should be removed from the scale; If it is between .200 and .300 and if it is deemed necessary, that item can be included in the scale or should be corrected.

If the correlation coefficient is between .300 and .400 , the item is considered to be good, if it is .400 and above the item is considered to be very discriminating. (Büyüköztürk, 2018; Ebel, 1965 cited., Erkuş, 2016b, p. 144). The reason for using the correlation calculation between the score given to each item in a scale and the total score of the items in a Likert-type scale is to ensure unidimensionality. This calculation should only be applied to homogeneous tests or subtests. Otherwise, although an item serves a sub-test very well, If the item-total correlation is low then this item needs to be taken out from the test (Erkuş, 2016b; Tavşanc1l, 2010). It is 
understood from Table 9 that the item-total test correlation values of AWBS are at a good level. As a result, it was determined that AWBS, which was applied to 287 people with 39 articles, had a 4-dimensional structure consisting of 23 items. Cronbach Alpha values were calculated to determine the preliminary reliability of the final structure of AWBS, which was obtained from the item analysis, before the construct validity. The Cronbach Alpha value is .85 for the first factor; .87 for the second factor; .65 for the third factor and .60 for the fourth factor. In addition, the value calculated for the whole scale is .90 .

\section{Reliability and Validity}

The scales whose factor structure was revealed should be applied to a different and larger research group to ensure the construct validity, and a confirmatory factor analysis should be performed on the data obtained (Erkuş, 2016a). Confirmatory factor analysis is a technique used at a higher level that tests whether the model created with theoretically determined variables and factors emerging in the explanatory factor analysis is confirmed by the new findings (Tabachnick \& Fidell, 2014).

AWBS, whose factor structure was determined, and psychometric qualities were examined, was applied to 711 academicians who had at least a doctorate and provided heterogeneity in terms of the relevant feature. Firstly, the suitability of the obtained data set for confirmatory factor analysis was tested. In this context, missing values, extreme values, normal distribution of the data set, correlation between items, sample size and sample fit (KMO and Bartlett test of sphericity) were considered (Field, 2013; Tabachnick \& Fidell, 2014). First, because of the lost value analysis, it is understood that there is no missing value in the data set. While determining multivariate extreme values, item scores are converted to standard scores ( $\mathrm{Z}$ scores) and values other than $|3|$ are evaluated as multivariate extreme values and are excluded from the analysis. In the extreme value analysis, the scores obtained in the measurements of the variables were converted into $\mathrm{Z}$ scores and the measurements $(\mathrm{n}=7)$ other than the $\mathrm{Z}$ score $(|3|)$ were removed from the data set (Tabachnick and Fidell, 2014). However, histogram and boxplot were also examined because they are important in reflecting extreme values. In the third stage, ShapiroWilk test, histogram graphics, the closeness of the median and arithmetic mean values and the skewness-kurtosis coefficients $(|2|)$ were considered in the multivariate normality tests of the data set. In the examination of the skewness and kurtosis values of the variables, it was observed that there was no item other than the value (|2|) (Field, 2013; Kalayc1, 2016), which is accepted as the criterion in the literature.

Kaiser-Meyer-Olkin (KMO) and Bartlett test results, which were examined to see whether the data set obtained from the number of samples in which the scale was applied was suitable for factor analysis, are presented below in Table 10.

Table 10. AWBS Kaiser-Meyer-Olkin, Barlett Test Results

Kaiser-Meyer-Olkin Research Group Qualification

Chi-square Value

Bartlett's Sphericity Value

*p<.001.

KMO value is suggested to be higher than .60 (Tabachnick \& Fidell, 2014). According to the $\mathrm{KMO}$ value (.902) reached at the end of the analysis, it was understood that the sample size
.902

4781,761

153

$.000^{*}$ 
was quite suitable for factor analysis. It was determined that Bartlett's sphericity test was also statistically significant, and the data came from multivariate normal distribution. These values show that the data set is very suitable for confirmatory factor analysis.

The data obtained were subjected to confirmatory factor analysis with AMOS 21.0 program. The fact that the item score averages of three items (3rd, 5th, 6th) are very low both in the trial application and in the actual application may indicate that the research group is uncomfortable with those items that might points potential bias (Erkuş, 2016b, p. 64). has been removed from the scale.

In the confirmatory factor analysis, the maximum likelihood technique, one of the estimation methods, was used because the sample size was high, and the distribution was normal. In the confirmatory factor analysis, CMIN / DF, CFI, GFI, AGFI, RMSEA, TLI, NFI, SRMR values were taken into consideration for the suitability of the structure. Regarding the cut-off points of GFI, AGFI and SRMR values from DFA fit indices:

Bentler and Bonnet (1980) stated that the cut-off point of GFI and AGFI fit index values was .90, while Marsh et al. (1988) stated that the lower cut-off point of GFI and AGFI values could be accepted as .85. McDonald and Moon-Ho (2002) state that the SRMR value should be below .05, while Hair et al. (1998) state that values below .08 may be acceptable for SRMR (as cited in Yaşar, 2014, p.119).

The acceptability of CFI and TLI values, one of the CFA fit indices, is considered as at least .90 (Basım, Çetin \& Tabak, 2009, p.119). RMSEA value .08 and lower values are accepted as good fit values (Gülbahar \& Büyüköztürk, 2008; Tabachnick \& Fidell, 2014). Kline (2011) states that it is acceptable that the ratio of chi-square to degrees of freedom (X2 / df) is less than 5.0. A measurement model consisting of 20 items under 4 dimensions related to academic writer's block was created. For this model, fit index values were obtained as X2 / df $=5,174$, $\mathrm{CFI}=.87, \mathrm{GFI}=.87, \mathrm{AGFI}=.84, \mathrm{RMSEA}=.077, \mathrm{TLI}=.85, \mathrm{NFI}=.85, \mathrm{SRMR}=.065$. These values show that the model does not provide the construct validity as such.

Since a theoretical model was tested, items that best represent the scale dimensions were preferred, and items 9 and 16 were removed. Thus, the construct validity of the scale was tried to be increased by determining the items that contributed the most to the explanation of the model.

Correction indexes suggested by the program were examined to correlate the error variances of some items. At this stage, it is recommended to make corrections between variables within the same structure and no more than three corrections (Şimşek, 2007, p.112). The error variances of the 20th and 21st items, which are in the same dimension and have a conceptual relationship, were correlated. The fit indices of the remaining 18 items after the necessary corrections were obtained as $\chi 2 / \mathrm{df}=4,53, \mathrm{CFI}=.90, \mathrm{GFI}=.90$, AGFI $=.87$, RMSEA $=.071$, TLI $=.90, \mathrm{NFI}=.88$, $\mathrm{SRMR}=.061$. It was understood that the fit values in the final form of the scale provided acceptable evidence for the construct validity of the scale. As seen in Figure 1, the structure with four implicit variables determined in the explanatory factor analysis is confirmed by the remaining 18 items in the scale. 


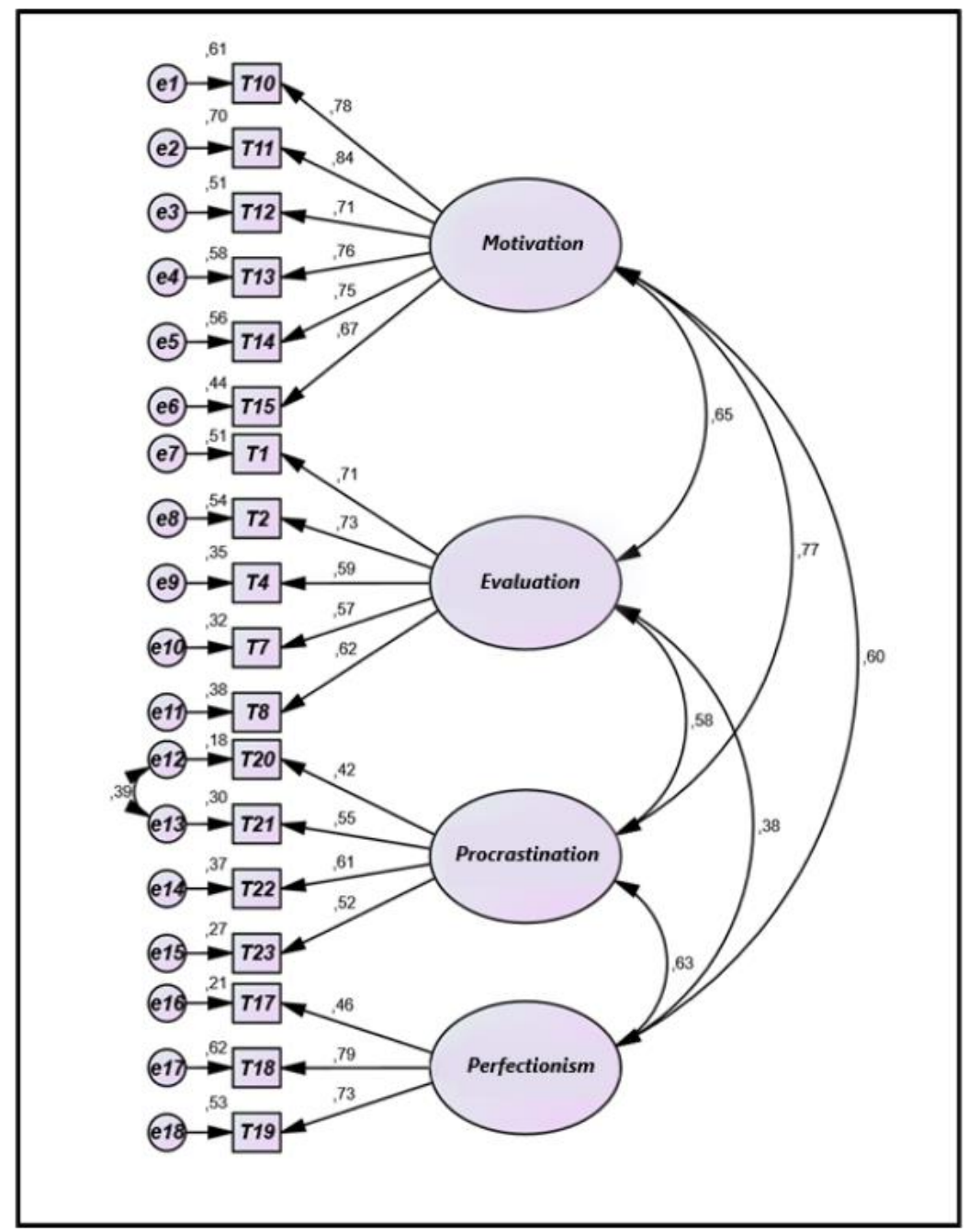

Figure 1. Confirmatory factor analysis information of the Academic Writing Block Scale

One of the ways to ensure construct validity is item-total test correlation analysis. In Table 11, the correlation values of the items with their size and the whole scale; Internal consistency coefficients of all dimensions and scale are presented.

Table 11. Item-Total Test Correlation and Reliability Values of AWBS

\begin{tabular}{|c|c|c|c|}
\hline & Item-Total Correlation & $\begin{array}{l}\text { Item-Total Correlation } \\
\text { (Within dimension) }\end{array}$ & Cronbach Alfa \\
\hline T10 & .748 & .805 & \multirow{6}{*}{.88} \\
\hline T11 & .762 & .854 & \\
\hline $\mathrm{T} 12$ & .665 & .772 & \\
\hline $\mathrm{T} 13$ & .700 & .802 & \\
\hline $\mathrm{T} 14$ & .720 & .802 & \\
\hline $\mathrm{T} 15$ & .688 & .726 & \\
\hline $\mathrm{T} 1$ & .539 & .747 & \multirow{5}{*}{.76} \\
\hline $\mathrm{T} 2$ & .515 & .758 & \\
\hline $\mathrm{T} 4$ & .563 & .709 & \\
\hline $\mathrm{T} 7$ & .472 & 680 & \\
\hline $\mathrm{T} 8$ & .537 & .685 & \\
\hline T20 & .466 & .730 & .64 \\
\hline
\end{tabular}




\begin{tabular}{llll}
$\mathrm{T} 21$ & .564 & .756 & \\
$\mathrm{~T} 22$ & .542 & .651 & \\
$\mathrm{~T} 23$ & .457 & 637 & .68 \\
\hline $\mathrm{T} 17$ & .325 & .760 & \\
$\mathrm{~T} 18$ & .596 & .817 & .775 \\
$\mathrm{~T} 19$ & .566 & .5 & \\
\hline
\end{tabular}

If an item's item-total test correlation coefficient is .200 or less, the item should be removed from the scale; If it is between .200 and .300 and if it is deemed necessary, that item can be included in the scale, or the item should be corrected.

If the correlation coefficient is between .300 and .400 , the item is considered to be good, if it is .400 and above, the item is considered to be very well discriminating (Büyüköztürk, 2018; Ebel, 1965, as cited in Erkuş, 2016b, p.144). The reason for using the correlation calculation between the score given to each item in a scale and the total scores of the items in a Likert-type scale is to ensure the unidimensionality feature. This calculation should only be applied to homogeneous tests or subtests. Otherwise, although an item fits a sub-test very well, the itemtotal correlation is low and this item is not included in the test (Erkuş, 2016b; Tavşanc1l, 2010).

In this study, the correlation coefficient of the 17th item is between .300 and .400 and is relatively low. However, the item-total test correlation value of the 17th item in its dimension is .760. Since this item's own dimension was determined to be consistent with the total test scores and distinctive at a good level, it was deemed appropriate to remain in the scale without correction.

Cronbach Alpha values were calculated to determine the reliability of the scale. Cronbach Alpha value was determined as for the first factor $.88 ; .76$ for the second factor; 64 for the third factor and .68 for the fourth factor. In addition, the value calculated for the whole scale was .88 . These values show that the scale has a good level of internal consistency and proves the construct validity (Tavşancıl, 2010).

The total score that can be obtained from the scale can be 18 to 90 points, and the high score reflects the high level of writer's block. The scale takes approximately 10 minutes to complete.

\section{Discussion, Conclusion and Recommendations}

In this study, a measurement tool has been developed that will allow obtaining valid and reliable measurements about academic writer's block. In the development of the scale, the establishment of the item pool, content validity, pre-trial application, trial application (factor analysis and pre-reliability test), validity and reliability tests were performed.

In the first step of the development process of AWBS, which was designed as a Likert type, the resources related to academic writing, writer's block and scale development were examined. In addition, face-to-face and electronic interviews were conducted with faculty members from different fields. To ensure the content validity of the items created as a result of the interviews, interviews were made with Turkish education experts, assessment and evaluation experts, and academicians who are experts in measurement and scale development in psychology. With the necessary arrangements in line with the suggestions, the scale was applied face to face to 20 faculty members in the pre-trial application. After these stages, the items were answered by 287 academicians in face-to-face interviews. Explanatory factor analysis was applied to the data obtained to reveal the structure of the scale. Thus, it was understood that the scale has a structure 
consisting of 23 items distributed to motivation, evaluation, procrastination, and perfectionism factors.

To ensure the construct validity of the scale, the factor structure of which was revealed, the scale form was applied to 711 academicians with at least a doctorate title, and confirmatory factor analysis and item-total test correlation test were performed. At this stage, the items that contributed the most to the explanation of the model created were determined and five items were removed from the form to strengthen the scale in reflecting the desired feature to be measured. Consequently, the results of the confirmatory factor analysis and the item-total test correlation test showed that the structure of the scale was confirmed by 18 items placed in four factors. Additionally, Cronbach Alpha values were calculated to determine the reliability of the scale. Cronbach Alpha value was determined as .88 for the first factor (motivation); .76 for the second factor (evaluation); .64 for the third factor (procrastination) and .68 for the fourth factor (perfectionism). In addition, the value calculated for the whole scale is .88. Thus, it was determined that the scale had a good internal consistency and construct validity was provided. On the basis of these findings, it can be stated that a valid and reliable four-factor Academic Writing Block Scale, which measures academic writer's block, consisting of 18 items, has been introduced to the academy.

In different studies (Birk, 2013; Boice, 1983a, 1983b, 1993, 1996; Boice \& Jones, 1984; Cayton, 1990; Elton, 2010; Hartley \& Knapper, 1984; Latta, 1995; Tucker, 1997), it has been stated that academicians and graduate students suffer from writing block during the reporting phase of the publishing process, although they have writing skills. "Writer's block" was shown as one of the reasons for academicians' difficulty in publishing (Boice \& Jones, 1984).

America, which has been doing research on the causes of academic writer's block and their solutions for nearly 40 years, ranks first with 3,618,989 publications in the list of countries that produce the most publications (TÜBİTAK, 2020). The concept of writing block has been a recent subject for academic inquiry in Turkey. The first studies that can be reached on these issues are by using the Writer's Block Questionnaire developed by Akpinar (2007) and Rose (1981); Zorbaz's (2010) research conducted by adapting the same scale as primary school students. In recent years, writer's block studies have increased, especially at secondary school and undergraduate levels. While the early studies on the issue of academic writing go back to the beginning of 1980s (Lowenthal \& Wason, 1981), Turkish academics did not show strong interest on the subject up until recent years.

This study, which develops a scale for academic writing block, can be regarded as important because it aims to fill the gap in the literature.

Screening studies for academics can be conducted with the academic writing block scale obtained from the research.

With the data acquired from the scale, it can be investigated whether academic writer's block differentiates in terms of variables such as academic units, faculties, colleges, title, associate professorship examination area, and gender. In addition, the scale can be used in generating hypotheses in studies to be conducted using mixed method, to expand the study for different components or to test the consistency of the findings.

With this scale, the academic writer's block level can be determined and the relationships between factors can be examined. However, guiding results can be obtained for academic 
writing productivity of scholars by determining the effect of skill, psychological (motivation, attitude, etc.), and sociocultural dimensions of writing in general and the dimensions of skill, psychological, sociocultural, and publishing process in the context of academic writing in particular.

This scale was created by working with academics working in Turkey. So, the scale needs to be adapted to different cultures. Thus, the academic writing block conditions of different academic cultures can be analysed comparatively. However, in order to measure the level and conditions of academic writing block of graduate students, it is necessary to adapt the scale by arranging the items in the context of the target audience.

Academic writing training centres such as Gazi, Frrat and İzmir Economy University, can be established in other universities in Turkey for the main purpose of increasing the selfconfidence of academicians by teaching academic writing skills and strategies. Turkish education experts who will work in these centres can give practical training. In this process, it is thought that the scale for academic writing block will make it easier for experts to identify problems and / or interpret existing findings.

\section{Acknowledgement}

I would like to thank Karadeniz Technical University Scientific Research Projects Coordination Unit, which contributed to the production of this study.

This study was produced from the doctoral thesis prepared by the first author under the supervision of the second author.

\section{References}

Akpınar, F. B. (2007). The effect of process-oriented writing instruction on writer's block, writing apprehension, attitudes towards writing instruction and writing performance (Unpublished master's thesis). Marmara University, Istanbul.

Baker, E. M. (1988). Writer's block and a cognitive process model of composing: recent research and implications for teaching (Unpublished doctoral dissertation). Iowa State University, Iowa.

Basım, N., Çetin, F. \& Tabak, A. (2009). The relationship between big five personality characteristics and conflict resolution approaches. Turkish Journal of Psychology, 24(63), 35-37.

Baştuğ, M. (2015). Effects of primary school fourth-grade students' attitude, disposition and writer's block on writing success. Education and Science, 40(180), 73-88.

Baştuğ, M., Ertem, İ. S. \& Keskin, H. K. (2017). A phenomenological research study on writer's block: Causes, processes, and results. Education and Training, 59(6), 605-618.

Birk, L. B. (2013). The sounds of silence: A structural analysis of academic "writer's block" (Unpublished doctoral dissertation). Boston College University, Boston. Retrieved from http://hdl.handle.net/2345/3315

Boice, R. (1983). Experimental and clinical treatments of writing blocks. Journal of Consulting and Clinical Psychology, 51(2), 183-191. Retrieved from https://doi.org/10.1037/0022006X.51.2șihnj

Boice, R. (19 85). Cognitive components of blocking. Written Communication, 33(10), 928940. Retrieved from https://doi.org/0803973233

Boice, R. (1990). Professors as writers. Okla: New Forums Press. 
Boice, R. (1993). Writing blocks and tacit knowledge. The Journal of Higher Education, 64(1), 19-54. Retrieved from https://doi.org/10.2307/2959976

Boice, R. and Jones, F. (1984). Why academicians don't write. The Journal of Higher Education, 55(5), 567-582.

Büyüköztürk, Ş. (2002). Factor analysis: Basic concepts and using to development scale. Educational Administration in Theory \& Practice, 32, 470-483.

Büyüköztürk, Ş. (2018). Sosyal bilimler için veri analizi el kitabı [Handbook of data analysis for social sciences]. Ankara: Pegem Akademi.

Castillo, M. (2014). Writer's block. American Journal of Neuroradiology, 35(6), 1043-1044. Retrieved from https://doi.org/10.3174/ajnr.A3729

Cayton, M. K. (1990). What happens when things go wrong: Women and writing blocks. Journal of Advanced Composition, 10(2), 321-337.

Daly, J. A. \& Miller, M. D. (1975). The empirical development of an instrument to measure writing apprehension. Research in the Teaching of English, 9(3), 242-249. Retrieved from https://doi.org/10.2307/40170632

Daly, J. A. \& Wilson, D. A. (1983). Writing apprehension, self-esteem, and personality. Research in the Teaching of English, 17(4), 327-341.

Dillman, D. A., Tortora, R. D. \& Bowker, D. (1998). Principles for constructing web surveys. Joint Meetings of the American Statistical Association, December, 1-16. Retrieved from https://www.researchgate.net/publication/2465935

Elton, L. (2010). Academic writing and tacit knowledge. Teaching in Higher Education, 15(2), 151-160. Retrieved from https://doi.org/10.1080/13562511003619979

Erkuş, A. (2007). Ölçek geliştirme ve uyarlama çalışmalarında karşılaşılan sorunlar [Problems encountered in scale development and adaptation studies]. Türk Psikoloji Bülteni, 13(40).

Erkuş, A. (2016a). Ölçek geliştirme ve uyarlama çalışmalarındaki sorunlar ile yazım ve değerlendirilmesi [Problems in scale development and adaptation studies, writing and evaluation]. In Ö. Demirel \& S. Dinçer (Eds.), Eğitim bilimlerinde yenilikler ve nitelik arayışı [Innovations in educational sciences and the search for qualifications] (p. 12211234). Ankara: Pegem Akademi.

Erkuş, A. (2016b). Psikolojide ölçme ve ölçek geliştirme-I, Temel kavramlar ve işlemler [Measurement and scale development in psychology - I, Basic concepts and operations. Ankara: Pegem Akademi.

Field, A. (2013). Discovering statistics using IBM SPSS. SAGE Publications. Retrieved from https://doi.org/10.1234/12345678

Gülbahar, Y. \& Büyüköztürk, Ş. (2008). Adaptation of assessment preferences inventory to Turkish. Hacettepe University Journal of Education, 35(35), 148-161.

Hartley, J. (2008). Academic writing and publishing: A practical handbook. Routledge.

Hartley, J. \& Knapper, C. K. (1984). Academics and their writing. Studies in Higher Education, 9(2), 151-167. Retrieved from https://doi.org/10.1080/03075078412331378814

Hettich, R. (1994). Writing apprehension: A critique. Indiana: Purdue University.

Huston, P. (1998). Resolving writer's block. Canadian Famil Physician, 44, 92-97. Retrieved from http://www.ncbi.nlm.nih.gov/pmc/articles/PMC2277565/pdf/canfamphys000470094.pdf

Kalayc1, Ş. (2016). SPSS Uygulamalı çok değişkenli istatistik teknikleri [SPSS Applied multivariate statistical techniques]. Ankara: Asil Yayınları.

Karakaya, İ. \& Ülper, H. (2011). Developing a writing anxiety scale and examining writing anxiety based on various variables. Educational Sciences: Theory \& Practice, 11(2), 691-708. 
Kline, R. B. (2011). Principles and practices of structural equation modeling. The Guilford Press.

Knox, K. (2017). Overcoming academic writer's block in two sentences. Retrieved from https://katelynknox.com/academic-writing/overcoming-academic-writers-block-twosentences/

Latta, S. M. (1995). Women and writer's block: An exploration of social and cultural influences upon the writing processes of five graduate student writers (Unpublished doctoral dissertation). Purdue University (UMI Number: 9601526).

Lowenthal, D. \& Wason, P. C. (1981). Academics and their writing. The Times Literary Supplement, 1977, 24 June, p. 781-781. (Reprinted in abridged form in Leonardo, 1981, 14, p. 57.)

Martineau, D. (2019). Nine ways to deal with academic writer. Retrieved from https://www.usrepresented.com/2019/03/30/nine-ways-to-deal-with-academic-writersblock/

Miller, K. M. (2010). Stranger than fiction: A study of student perceptions of writer's block and film in the composition classroom. (Unpublished doctoral dissertation), Indiana University of Pennsylvania, Pennsylvania. Retrieved from http://search.proquest.com/docview/749927758?accountid=16645

Murray, D. M. (1986). One writer's secrets. College Composition and Communication, 37(2), 146-153. https://doi.org/10.2307/357513

Murray, R. (2015). Makale nasıl yazılır [Writing for academic journals] (Şakir Çınkır, Trans.). Ankara: An1.

Petzel, T. \& Wenzel, M. (1993). Development and initial evaluation of a measure of writing anxiety. Retrieved from http://eric.ed.gov/?id=ED373072

Poff, S. I. (2004). Regimentation: A predictor of writer's block and writing apprehension (Unpublished doctoral dissertation). University of Southern California, California. (UMI Number: 3155461). Retrieved from https://vcu-illiad-oclcorg.proxy.library.vcu.edu/illiad/illiadsso/illiad.dll? Action $=10 \&$ Form $=75 \&$ Value $=8626$ 01

Polat, Y. (2012). Examining factor analysis methods comparatively and applying to animal husbandry trial (Unpublished doctoral dissertation). Çukurova University, Adana.

Rose, M. (1981). Questionnaire for identifying writer's block. Retrieved from https://eric.ed.gov/?id=ED236652

Rose, M. (1984). Writer's block: The cognitive dimension. Carbondale: Southern Illinois University Press. Retrieved from https://eric.ed.gov/?id=ED248527

Şimşek, Ö. F. (2007). Yapısal eşitlik modellemesine giriş [Introduction to structural equation modeling]. Istanbul: Ekinoks.

Tabachnick, B. \& Fidell, L. (2014). Using multivariate statistics (6. ed). Pearson.

Tavşancıl, E. (2010). Tutumların ölçülmesi ve SPSS ile veri analizi [Measuring attitudes and data analysis with SPSS]. Ankara: Nobel Yayın Dağıtım.

Tezbaşaran, A. (2008). Likert tipi ölçek hazirlama kllavuzu [Likert type scale preparation guide]. Retrieved from https://www.academia.edu/1288035/Likert_Tipi_\%C3 \%961\%C3 \%A7ek_Haz\%C4\%B1rlama_K\%C4\%B1lavuzu

The Scientific and Technological Research Council of Turkey [TUBITAK]. (2016). Dünya, ülkeler ve gruplar bilimsel yayın sayısı (2010-2015) [World, countries and groups number of scientific publications (2010-2015)]. Retrieved from https://cabim.ulakbim.gov.tr/bibliyometrik-analiz/turkiye-bilimsel-yayin-performansraporlari/ 
The Scientific and Technological Research Council of Turkey [TUBITAK]. (2020). Ülkelerin bilimsel yayın sayıs1 (2015-2019) [Number of scientific publications in countries (20152019)]. Retrieved from https://cabim.ulakbim.gov.tr/bibliyometrik-analiz/

Tucker, M. T. (1997). Academic women and writer's block: Mapping the terrain (Unpublished doctoral dissertation). University of Massachusetts Amherst (UMI Number:9737590).

Yaşar, M. (2014). Developing an attitude scale related to scientific research methods course: validity and reliability. Journal of Educational Sciences Research, 4(2), 109-129.

Yaşlıoğlu, M. M. (2017). Factor analysis and validity in social sciences: Using exploratory and confirmatory factor analysis. Istanbul University Journal of the School of Business, 46(special issue), 74-85.

Yıldırım, A. \& Şimşek, H. (2011). Qualitative research methods in the social sciences. Ankara: Seçkin.

Zorbaz, K. Z. (2010). The relationship between middle school student's writing apprehension and blocking with their written expression skills (Unpublished doctoral dissertation). Gazi University, Ankara. 


\title{
Appendix
}

\section{Academic Writing Block Scale}

\author{
Motivation \\ T12 I need to take breaks over and over while writing. \\ T10 It takes hours to write the first paragraph. \\ T11 It happens that hours pass from thinking how to write until I start writing. \\ T14 I need a long time to create an academic text. \\ T10 It takes a lot of time to get ready to write. \\ T15 It would be very difficult for me to start writing again after spending time for other activities \\ (lecture, spending time with my family, etc.) in the scientific writing process.
}

T2 Criticism of my previous articles demotivates me from writing new articles.

T1 The thought that criticism of an academic paper will hurt my pride causes my writing to progress slowly.

T7 When I think that very few people will read it after I have my articles published, I have the feeling that I am trying in vain.

T4 I finish my academic text in a longer time with the idea of writing in a quality worthy of my title.

T8 When I remember that I must write, I cannot continue writing.

Procrastination

T23 I cannot finish my writing if I do not get in touch with people during the academic writing process.

T22 The longer I take a break after finishing an article, the harder it will be for me to start writing again.

T20 I cannot start writing before I have access to all the resources related to my scientific study.

T21 I wait until I feel ready to write an academic text.

\section{Perfectionism}

I make corrections in terms of spelling and punctuation in the first draft.

T18 I wait until I find the most accurate expression or the most beautiful sentence, I will not move forward.

T19 I would have deleted and rewrote some words or the entire sentence several times until I finished a sentence. 